\section{The Laboratorial Diagnosis for G6PD Deficiency in Multiethnic Population}

De Souza Ondei L ${ }^{1}$, Silveira LM², Bonini-Domingos CR $^{2 *}$, Orlandini LC ${ }^{2}$, Leite AA ${ }^{3}$, Ricci O4, and Machado RLD

${ }^{1}$ Câmpus Anápolis de Ciências Exatas e Tecnológicas- Henrique Santillo, Universidade Estadual de Goiás, Anápolis, GO, Brazil

${ }^{2}$ Departamento de Biologia, Laboratório de Hemoglobinas e Genética das Doenças, Hematológicas, Instituto de Biociências, Letras e Ciências Exatas, Universidade Estadual Paulista, São José do Rio Preto, SP, Brazil

${ }^{3}$ Departamento de Análises Clínicas, Faculdade de Ciências Farmacêuticas, Universidade Estadual Paulista, Araraquara, SP, Brazil

${ }^{4}$ Hemocentro, São José do Rio Preto, SP, Brazil

${ }^{5}$ Universidade Federal Fluminense, Brazil

\section{Abstract}

The deficiency of glucose-6-phosphate dehydrogenase (G6PD) is the most frequent of the causes of hemolytic anemias by enzymopathies. Considering the high prevalence of these alterations and the miscegenated characteristic of the Brazilian population, the objective of this study was to investigate the frequency of this genetic affection, correlating them with the ethnic aspects and with the importance of the methodologies used for the routine laboratory diagnosis. A total of 544 peripheral blood samples collected after informed consent were analyzed from individuals aged 16-65, including 426 blood donors and 118 from individuals in an educational institution. The samples were submitted to the classic laboratory diagnosis methods for G6PD deficiency, with subsequent confirmation by complementary and specific methodologies. For the G6PD deficiency, a frequency of $3.86 \%$ was found, with $81.48 \%$ of the samples presenting the mutation A-202 (G> A), of African origin. The high frequency of G6PD deficiency reinforces the importance of investigating these hereditary conditions with due laboratory confirmation especially in mixed populations.
\end{abstract}

Keywords: Enzymopathie; A-202 (G>A) variant; Frequency; Brazilian population

\section{Introduction}

Globally, the glucose-6-phosphate dehydrogenase (G6PD) deficiency is the most common enzymopathy, affecting about 400 million people, as a result of mutations that alter normal expression of the enzyme [1]. The G6PD provide nicotinamide adenine dinucleotide phosphate (NADPH) that participates, continuously, in glutathione cycle (GSH) to protect erythrocytes against induced damage by hydrogen peroxide and free radicals and prevent acute hemolytic anemia [2-5]. Since, G6PD deficiency become the erythrocytes more vulnerable to the effects of oxidizing agents, such as anti-malarial drugs, analgesics composed of acetylsalicylic acid and sulfone, that makes the diagnosis of deficiency essential to warn patients about the risk of hemolytic crisis [6].

In Brazil, G6PD deficiency has high incidence, which is due to miscegenation characteristic of the population composed of different ethnic groups. This deficiency has different prevalences throughout the country and are important genetic markers of ethnic groups and populations $[7,8]$.

Thus, observing the high prevalence of G6PD deficiency and miscegenation characteristic of the Brazilian population, we consider of great importance to adequate laboratory investigationmakes the diagnosis of deficiency essential to warn patients about the risk of hemolytic crisis [9]. For diagnosis, are described in the literature various qualitative techniques, quantitative and molecular with varying degrees of sensitivity and specificity, making it important to the association methodologies [10]. In this way, the G6PD deficiency screening in individuals without clinical symptoms has done through various methods of diagnosis available in the laboratory routine in this study.

\section{Materials and Methods}

\section{Blood samples, population and study sites}

This study analyzed 544 samples of peripheral blood collected after informed consent from individuals aged between 16 and 65 years, 346 men $(63.60 \%)$ and 198 women (36.40\%). According to ethnicity, 382 were Caucasian (70.22\%), 74 african descendants (13.60\%) and 88 from different ethnic backgrounds (16.18\%), including Eastern and crosses between Caucasian and african descent. Of the total assessed 426 samples were from the Blood Center of São José do Rio Preto, receiving donors from different cities of the northwest region of São Paulo and 118 university students.

\section{Screening for G6PD deficiency}

For the G6PD deficiency screening the samples were evaluated by the qualitative method of Brewer, which is based on the formation of methemoglobin $\left(\mathrm{Fe}^{+3}\right)$ by oxidative action of nitrite on hemoglobin $\left(\mathrm{Fe}^{+2}\right)$. In the presence of methylene blue, there is stimulation of the pentose phosphate pathway with production of NADPH, converting the oxidized hemoglobin to its reduced form. Reduction rate is proportional to erythrocyte G6PD activity. However, the test is not specific for G6PD deficiency [11].

\section{G6PD activity}

The G6PD activity was determined for the positives in screening, using the method proposed by Beutler [12], which measures the reduction rate NADP to NADPH when a hemolysate is incubated with glucose 6-phosphate. The enzymatic activity is expressed in UI.gHb ${ }^{-1}$.

*Corresponding author: Dr. Claudia Regina Bonini-Domingos, UNESP/IBILCE Laboratório de Hemoglobinas e Genética das Doenças Hematológicas, Rua Cristóvão Colombo, 2265, Jardim Nazareth, São José do Rio Preto, SP, CEP 15054-000, Brazil, Tel: 173221 2392; E-mail: claudiabonini@sjrp.unesp.br

Received November 13, 2017; Accepted February 07 2018; Published February 12, 2018

Citation: De Souza Ondei L, Silveira LM, Bonini-Domingos CR, Orlandini LC, Leite AA, et al. (2018) The Laboratorial Diagnosis for G6PD Deficiency in Multiethnic Population. J Mol Genet Med 12: 325 doi:10.4172/1747-0862.1000325

Copyright: () 2018 De Souza Ondei L, et al. This is an open-access article distributed under the terms of the Creative Commons Attribution License, which permits unrestricted use, distribution, and reproduction in any medium, provided the original author and source are credited 


\begin{tabular}{|c|c|c|c|c|}
\hline Variables & \multicolumn{2}{|c}{ Females } & \multicolumn{2}{c}{ Males } \\
\hline Results & Positive & Intermediate & Positive \\
\hline Blood Center & 3 & 11 & 12 \\
\hline Educational Institution & 3 & 4 & 22 \\
\hline Total & 6 & 15 & 0 \\
\hline
\end{tabular}

Table 1: Positivity in Brewer test according to gender and origin of the sample.

$\min ^{-1}$ at 37 in $\mathrm{pH} 8.0$ being a unit of enzyme activity (IU) defined as the amount of enzyme that reduces $1 \mu \mathrm{mol} \mathrm{NADP}^{+}$per minute at $37^{\circ} \mathrm{C}$ $[13,14]$. The normal reference range used under the conditions local laboratory testing and population group ranged from 8.03 to 14.80 UI.gHb ${ }^{-1} \cdot \mathrm{min}^{-1}$ at $37^{\circ} \mathrm{C}$.

\section{Molecular analysis to detect G6PD A-202 variant}

The primer sense 5' CAG CCA CTT CTA ACC AC 3' and the primer antisense 5' AAC CAG GCT GGG GGA G 3' were used for the A-202 (G>A) mutation for G6PD deficiency by PCR-RFLP, amplifying a $314 \mathrm{bp}$ fragment. The amplification process was performed by prior denaturation of $94^{\circ} \mathrm{C}$ for five minutes, plus 35 cycles of $94^{\circ} \mathrm{C}$ for one minute, $55^{\circ} \mathrm{C}$ for one minute, $72^{\circ} \mathrm{C}$ for 50 seconds, followed by a final $72^{\circ} \mathrm{C}$ for five minutes. After digestion with the NIa III enzyme (New England BioLabs), the normal allele generates a $314 \mathrm{bp}$ fragment and the mutant allele two fragments, one of $218 \mathrm{bp}$ and the other of $96 \mathrm{bp}$ [13].

\section{Results}

For screening for G6PD deficiency, the samples were first evaluated by Brewer Test. Of the 544 samples, 20 (3.68\%) were positive, six females and 14 males; 37 (6.80\%) were the result of intermediate color (between positive and negative), being classified as doubtful. Of these, 15 were female and 22 males. In $487(89.52 \%)$ remaining samples, the result was negative. As this is a very sensitive colorimetric method, it is common the presence of intermediate results. Table 1 was related to test positivity according to gender and origin of the sample.

The samples which showed positive and equivocal result in the screening test were subjected to the test Beutler in 1984, to determine the activity of G6PD enzyme. Of the 57 samples with suspected G6PD deficiency in Brewer test, the enzyme deficiency was confirmed in 27 of them, 20 with positive preliminary results in the screening test, and seven of the 37 who had dubious results. Thus, we found a positive rate at $47 \%$ test, and the error percentage was $53 \%$. The frequency of G6PD deficiency for the studied group was equal to $4.96 \%$ and removing this group of six related individuals, the frequency obtained was $3.86 \%$. Considering only the sample group consisting of the male blood donors, there were 14 samples with G6PD deficiency, corresponding to $4.59 \%$.

Evaluating A-202 mutation (G> A) in 27 samples with G6PD deficiency, as confirmed by enzyme dosage, the mutation was found in 22 of them, which corresponds to $81.48 \%$ of group G6PD deficiency and $4.04 \%$ of the study sample. We also point out that in a female sample, there was the presence of the mutation A-202 (G>A) for G6PD.

\section{Discussion}

In the present study, the trace of G6PD deficiency was performed in healthy adults. Whereas most polymorphisms to G6PD deficiency is asymptomatic and the hemolytic crisis is usually triggered by external factors, the trace to individuals without signs or symptoms of hemolytic anemia is of great importance as it allows alert wearers on the susceptibility to hemolytic crisis during infections, after ingestion of certain drugs or other oxidizing agents.

Tracking the G6PD deficiency was carried out primarily by
Brewer's test, which is widely spread in routine laboratory screening of enzyme deficiency, due to the low cost of reagents and equipment, and its simple execution. The samples showed positive result in the test of Brewer, G6PD deficiency was confirmed in $100 \%$ when the enzyme was quantified by Beutler's method. However, in samples with dubious results, only $20 \%$ confirmed the change, demonstrating the need for additional specific methodologies.

The percentage equal to $53 \%$ false positive results that we found for the Brewer method was superior to $6 \%$ described by Long et al. (2000) [14]. This high frequency may have been due to the implementation of the enzyme dosage in all samples with dubious results, once the G6PD deficiency can go unnoticed in those samples that do not present a totally positive result for Brewer's test.

The frequency of G6PD deficiency of 3.86\%, described in this work, was superior to the $2.38 \%$ for the northwestern region of São Paulo State [15]. In Rondonia, the estimated frequency, using only the method of Brewer for the diagnosis, was 3.3\% [16]. Other researches, using specific methodologies, showed for the southern region, frequency equal to $1.4 \%$ of the total deficiency of G6PD and $6.4 \%$ for partial disability [17]. It should be noted that the frequency of enzyme deficiency among male blood donors was greater than those described for the others Brazilian region with $1.73 \%$ [14] and $3.65 \%$ [18].

Most of the samples with G6PD deficiency $(81.48 \%)$ presented the mutation at-202 $(\mathrm{G}>\mathrm{A})$, which is a variant of African origin, clinically benign, and the most frequent in Brazil. In the region of Campinas/SP a frequency of $97.3 \%$ was found for the mutation-202 (G>A) among blood donors with G6PD deficiency, a proportion similar to that described in our work [19]. Other studies also show the presence of rare changes in Brazil, as the Mediterranean variants, A- $(968 \mathrm{~T}>\mathrm{C}, 376>\mathrm{G})$, G6PD Seattle $(844 \mathrm{G}>\mathrm{C})$, G6PD Santamaria $(542 \mathrm{~A}>\mathrm{T}, 376 \mathrm{~A}>\mathrm{G})$, G6PD Tokyo $(1246 \mathrm{G}>)$, and others $[13,18,19]$.

\section{Conclusion}

From the results obtained it was concluded that the high frequency of G6PD deficiency in the examined population, reinforces the importance of research of these hereditary diseases, including blood donors, in which the search of G6PD deficiency is recommended, with a view to improving the quality of the blood to be transfused, as well as the orientation of the carriers for a better quality of life [14].

Considering the low specificity of screening tests and the racially mixed Brazilian population characteristics there is the need of proper laboratory confirmation, through the combined use of methodologies. The great participation of various ethnic groups in the formation of the population can be confirmed through the screening for genetic diseases, whose ID allows a better educational intervention and guidance to carriers for the risk of hemolysis by the use of drugs or contact with oxidizing agents.

\section{References}

1. Bubp J, Jen M, Matuszewski K (2015) Caring for Glucose-6-Phosphate Dehydrogenase (G6PD)-deficient patients: Implications for pharmacy. Pharmacotherapy 40: 572-574. 
Citation: De Souza Ondei L, Silveira LM, Bonini-Domingos CR, Orlandini LC, Leite AA, et al. (2018) The Laboratorial Diagnosis for G6PD Deficiency in Multiethnic Population. J Mol Genet Med 12: 325 doi:10.4172/1747-0862.1000325

2. Howes RE (2013) G6PD deficiency: Global distribution, genetic variants and primaquine therapy. Adv Parasitol 81: 133-201.

3. Monteiro WM, Val FFA, Siqueira AM, Franca GP, Sampiao VS, et al. (2014) G6PD deficiency in Latin America: A systematic review on prevalence and variants. Mem Inst Oswaldo Cruz 109: 553-68.

4. Ghashghaeinia M, Giustarini D, Koralkova P, Köberle M, Alzoubi K, et al. (2016) Pharmacological targeting of glucose-6-phosphate dehydrogenase in human erythrocytes by Bay 11-7082, parthenolide and dimethyl fumarate. Scientific Reports 6: 1-2

5. Valencia SH, Ocampo ID, Arce-Plata MI, Recht J, Arévalo-Herrera M (2016) Glucose-6-phosphate dehydrogenase deficiency prevalence and genetic variants in malaria endemic areas of Colombia. Malar J 15: 291.

6. Sánchez TA, DP Núñez, Luengo MS (2003) Anemia hemolítica por deficiência de G6PD y estrés oxidativo. Rev Cuba de Invest Bioméd 22: 186-191.

7. Beutler E (2008) Glucose-6-phosphate dehydrogenase deficiency: A historica perspective. Blood 111: 16-24

8. Compri, MB, Saad STO, Ramalho AS (2000) Investigação genéticoepidemiológica e molecular da deficiência de G6PD em uma comunidade brasileira. Cad Saúde Pública 16: 335-342.

9. Minucci A, Giardina B, Zuppi C, Capoluongo E (2009) Glucose-6phosphate dehydrogenase laboratory assay: How, when, and why? IUBMB Life 61: 27-34.

10. Johnson MK, Clark TD, Njama-Meya D, Rosenthal PJ, Parikh S (2009) Impact of the method of G6PD deficiency assessment on genetic association studies of malaria susceptibility. PLOS One 4: e7246.
11. Brewer GJ, Tarlov AR, Alving AS (1960) Methaemoglobin reduction test. A new, simple, in vitro test for identifying primaquine-sensitivity. Bull World Health Organ 22: 633-640.

12. Beutler E (1984) Red cell metabolism. A manual of biochemical methods (3rd edn), Grune and Stratton, Inc, London, UK.

13. Hamel AR, Cabral IR, Sales TS, Costa FF, Olalla Saad ST (2002) Molecular heterogeneity of G6PD deficiency in an Amazonian population and description of four new variants. Blood Cells Mol Dis 28: 399-406.

14. Compri MB, Polimeno NC, Vieira MJA, Saad STO, Ramalho AS (2000) Programa comunitário e deficiência de G-6-PD no Brasil. Rev Bras Hematol Hemoter 22: 33-39.

15. Leite ERM, Lessi JHC, Mascarin DB, Leite AA (1996) Pesquisa de deficientes em G6PD nos doadores de sangue da região de Araraquara. Bol Soc Bras Hematol Hemot 18: 337.

16. Katsuragawa TH, Soares Gil LH, Stábile RG, Pires MG, Bonini-Domingos CR (2004) Avaliação da incidência da deficiência de Glicose-6-Fosfato Desidrogenase (G6PD) e perfil hematológico em indivíduos de uma região de Rondônia. Rev Bras Hematol Hemoter. 26: 268-73.

17. Castro S, Weber R, Dadalt V, Tavares V, Giugliani R (2006) Prevalence of G6PD deficiency in newborns in the south of Brazil. J Med Screen 13: 85-86.

18. Nicolielo DB, Ferreira RIP, Leite AA (2006) Atividade da 6-fosfogliconato desidrogenase em deficientes de glicose-6-fosfato desidrogenase. Rev Bras Hematol Hemoter 28: 135-38.

19. Saad STO, Salles TSI, Carvalho MHM, Costa FF (1997) Molecula characterization of glucose-6-phosphate dehydrogenase deficiency in Brazil. Hum Hered 47: 17-21. 